\title{
The Essays of Francis Bacon: Inspiring Perfection
}

\author{
Farhana Chowdhury ${ }^{*}$
}

\begin{abstract}
To make himself a perfect one and to live a life in utmost contentment is an indispensable desire of every human being. The proper utilization of knowledge and power helps a man enjoy a life of paramount peace and tranquility. But if he goes wrong, it will be a fatal disaster for him that might also make his life nothing but a stockroom of sighs and tears. In order to be a perfect and successful one human definitely needs someone who always helps him see the right path. He is certainly in need of some idols who will never let him be engulfed by confusion. Here comes the name of Francis Bacon, a man from the Renaissance whose essays work tremendously as a source of inspiration and courage and motivate man to respond to the appeal of goodness. He persuades man to deal with the prickles of life with a zeal to win over every difficulty. This paper, with an aim to let people imbibe the spirits of Bacon's essays into their hearts, is an endeavor to explore how his essays inspire its readers to live simply but gorgeously while striving best to attain perfection and to enjoy its strength and beauty.
\end{abstract}

Keywords: Human world, Chaos, Human, Knowledge and Perfection.

\section{Introduction}

The great man whose essays are being honored today is a universal genius. His practical activities are applicable in most of the spheres of life. Before discussing the messages of Bacon's essays and their role to inspire people to walk on better ways, we must understand the relationship between human and an apt guideline. This relationship could be comprehended by a simple example: the relationship between fish and water. Water is life to fishes. But if water is contaminated with toxicity, surely it will bring a disastrous consequence to fishes. Likewise, guidelines are available but before following them, we must know whether they lead to the life of beauty or to the life of nightmares. If man fails to get a guide who loves to serve others with wisdom and prudence, he is surely going to be deceived by the deceiving

* Farhana Chowdhury, Assistant Professor, Dept. of English, Bangladesh Islami University (BIU). E-mail: farhana2180@gmail.com 
world. Usually, parents, educational institutions and teachers play a vital role to guide human. Whatever they are they can be the resourceful agent to inspire the followers to make discrimination between good and evil and to do every possible thing for the betterment of themselves and their families and in broader level, of the society and the country. That active agent can set examples from the past and the current world which will be very inspirational for the followers to shun away the satanic appeals and to choose the right track. Both the institution and an individual one has to play the vital role to the denizens so that they can make themselves free from any evil path and thus, they can achieve an unspoiled, long and healthy life.

The picture of today's world shows that men have wrongly used their talents. They have made this world a waste land of horror instead of an amazing land of beauty and bliss. Human society has completely lost all sorts of humanity. It is loaded with cruel and machine like people who never hesitate to extinguish the rights of others and even shed the blood of the innocent ones just for a few pennies as if they had completely forgotten that: "All that is on earth will perish: but will abide forever the Face of thy Lord, full of Majesty, Bounty, and Honour" (Qur'an, 55: 26-27). Shakespeare's message that "all the monuments, palaces, ornaments, and jewels are the subjects to decay" is completely eclipsed from human minds. Consequently, a large part of human world has only learnt how to live for oneself. The words like family, friendship, honesty, values, dedication, patience and sacrifice are absent from the glossary of today's human beings. They have entered into a new dark age where treachery, frustration, tears, and bloodshed await them. So, it is the demand of time to let people know the values of principles and morality. It is the demand of humanity to inspire all to ignore all the malicious things and to walk on the righteous path for the sake of self-development and thus, to take vigilant attempts to serve the society.

Here comes the importance of studying the essays of Francis Bacon (1561-1626). Bacon was a man who could dive into the deepest core of human hearts to feel them and to identify what ails them most and what soothes their minds. He knew it best to remind people of their objects of life and show them the ways to fulfill those. His essays are all about men. They are the treasures of wisdom which help men to deal with the affairs of the world. They have become the storehouse of practical philosophy replete with wit, keen observation and grave judgments. Hugh Walter rightly says, "With Bacon we enter the world of stark realities, rational and grave. To him goes the credit of being the first of English essayists, as he remains, for sheer mass and weight of genius, the greatest" (Alam, 2014). All his essays reveal that by 
making a proper use of intellect and knowledge a man can handle any circumstance. His essays motivate their readers to deal with the riddles of daily life bravely and to strangulate all those forces which actually make people confused and to some extent, disappointed. The essays are truly meant to enrich the lives of not only the people from the Renaissance but also for the people of all ages. The messages of Bacon's essays definitely encourage people to overlook every evil trap and to grab all which can beautify life in order to let each individual attain precision in his personal and social affairs and gradually, to become a role model for others.

\section{Bacon is a Man for Men of All Ages}

Francis Bacon, a man of many talents, possesses an intellect of highest order. He was an English philosopher, statesman, scientist, jurist, orator and author. He served both as Attorney General and Lord Chancellor of England. He provided much of the inspiration for the establishment of the Royal Society of London for the improvement of the Natural Knowledge. Indeed, Bacon was an eloquent prophet of the new era. $\mathrm{He}$ supplied the impulse which broke the medieval conceptions pointing at the progress in philosophy, science and society. Moreover, he gives the world a series of essays which confirm him a man thinking for the benevolence of men. Though the essays are the products of his age, still they are read and admired confirming their importance upon all ages. There are the critics who find the presence of a man of science, of martial affairs, of law and an orator and a statesman in his essays. But he appears as a guide as well who wants to move people towards the practice of knowledge and truth. $\mathrm{He}$ is a philosopher who is deeply interested in the pursuit of real life and justice, and he is a moralist who shows the distinction between right and wrong and urges them to tread the right path confidently. His messages are to feed human with the proper and real knowledge which will certainly help them deal with any problem at any time. He inspires people to be on the path of truth as he believes that truth is like the clear day light which throws away all the confusions and provides people the courage to face life in its real form. All these are the observations of a philosopher-cum-moralist and of course, of a guide whose object is manifestly to instill into the minds of his readers a love of truth and a sense of unity and courage which enable a man to fight against all sorts of adverse situation, to reach at the uttermost stage of perfection and make all happy. He believes that a man is in a continual journey to make himself better from yesterday. This striving spirit is the base spirit of mankind to make themselves free from sin and deadly factors. Bacon is a man of words and of actions. What he preached was practically executed by him. In order to offer tribute to this great man 
Fulton H. Anderson says: "Francis Bacon was by nature a nurturer and reformer. Always he desired to make things 'better' as he said" (Anderson, 1962: 12). His essays have been classified under the following heads: (i.) man in his relation to himself, (ii.) man in his relations to the society, and (iii.) man in his relations to his Maker that is, God. The thoughts expressed in the essays make a man complete. They cover all the phases of life. They possess a magical power to encourage people to have all which have the splendor to form a beautiful life and to avoid all which can ruin life. It is the time to see how the messages of Bacon's essays can help human beings to walk on the worthy path to be the perfect one aiming at establishing order in this chaotic world.

\section{The Essays are the Reminder of Goodness and Hope for Humanity}

What is human? How he or she should be? Leaving aside the hypothesis human could be defined as one and only being who has rational faculty which helps him understand what is good and what is to be avoided. This is the innate nature of human. We never find an infant to like to wear a quilt in hot summer days. We never see a child feeling comfortable in cool water in frosty winter. Human always reflects the sign that every good thing is welcome. He has the knowledge gifted by the Creator to know the righteous path. A human being is honored with endless potential for knowledge. He is the only creature to whom God has granted the potential perfection of supremacy over universal forces and other creatures. He has been blessed with every required resources to make this world a heaven. But today's picture of human world is extremely heart rendering. Human has lost his power to think anything good. They are engaged in violence of all sorts. The following image added on August 2016 in Wikipedia is showing the total area of the world involved in violence or conflicts or civil war.

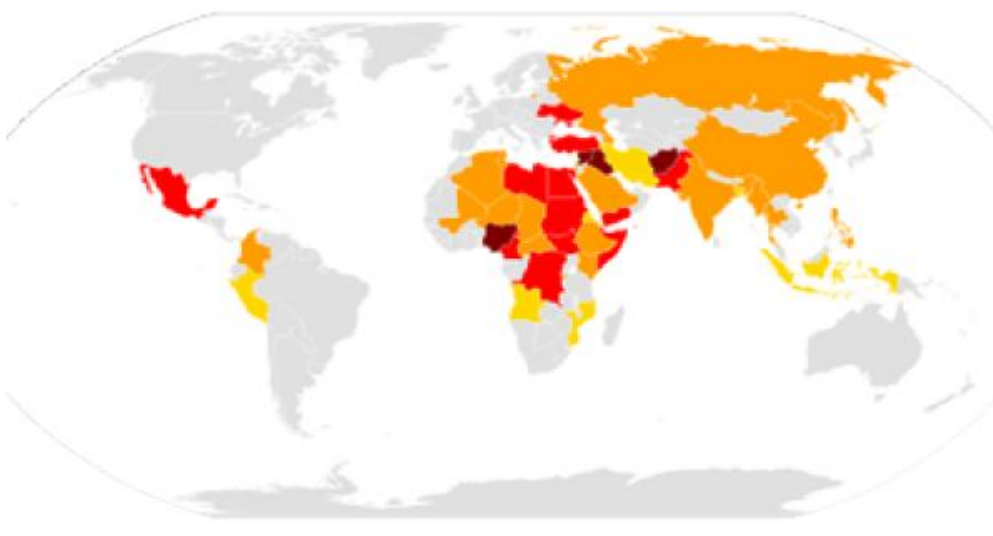

Figure 1 
In this figure, the colored areas mark a large part of the world being affected with violence. Besides, The Daily Express revealed a report on August 16, 2014 prepared by Sarah and Harris which stated that only 11 countries out of 162 countries in the world were at peace being free from any sort of conflict. (Sarah and Haris: 2014) World Health Organization (WHO) in World Report on Violence and Health confirmed that each year more than 1.6 million people worldwide lose their lives to violence.

What happened to mankind? Why are they so disturbed and violent? The answer is simple. Human forgets humanity. They forsake the path of knowledge whereas this path is mandatory for every individual. People get involved in "treachery, deceit, backbiting, jealousy and hypocrisy resulting in disobeying of the traditional and moral values, illiteracy, poverty, political unrest, injustice, frustration, unemployment, family disorder and suicidal tendency." (Islam: 2012) These deadly factors are distorting all the principles and characteristics of a humanity and society. They are breeding criminal activities like murder, robbery, drug addiction, child labor, women and children trafficking, prostitution and many more heinous crimes around the world (Islam, 2012: 74). Nowadays, whenever we open a newspaper our eyes just get stuck at the news of deadly activities. Man is being killed by the hands of man for tiny causes. They are not safe even at their home. Women are humiliated and then, killed brutally. School goers do not know whether they can return home safely or not. Adults do not know whether they can keep their hard earned property safe or they are to surrender before a single bullet. People do not know how to survive let alone living a happy life. People do not know whom to trust let alone living in unity. All these create "an unnatural, undesired and suffocated situation affecting all classes of people. The suffocating situation of the society hinders the natural, systemic and satisfying growth of a man, a society and thus, of a nation" (Timothy and Jonvan: 2004). There remains no confusion to say that it is high time we kindled the light of knowledge, humanity and hope. Mankind is to be dragged out from violence. They need to be convinced that life is beautiful when it is accompanied by ethics and morality. To serve this purpose, books, essays, documentaries, research papers and lectures work as very effective endeavors. If we study Bacon's essays it would be definitely felt that to stir people to seek knowledge is the fundamental focus of them. "We find Bacon implying that the only worthwhile and theoretical knowledge is that which serve the realm of human action. This is the seed of a vision which was nurtured and protected in his thought" (Bowen, 1993: 212). Undoubtedly, it could be asserted that the appeal to involve in attaining knowledge to determine the actions and plans for bringing 
about a development in all affairs of life and to march forward towards attaining perfection, tranquility and peace is the chief focus of the essays:

\section{i.) Conveying the Need of Unity and Friendship among All}

Bacon says that men's craving to live with others let them come close to one another. Gradually, they start to share their sorrows, joys, fears and hopes which help them to keep reliance on others. This sort of practice while establishing a bond of friendship and unity among all helps them to stand beside others in their weal and woes. In "Of Friendship", Bacon opines that friendship undoubtedly diminishes people's misery and multiplies joy. Man, leading a life of good relationship with others, can converse with others whenever time demands which helps him to sharpen his wits and take the right decision. Thus, Bacon inspires universal brotherhood. Bacon reveals that gross fault is committed when man thinks himself alone finding no one to counsel; no one to share: "A principal fruit of friendship is the ease and discharge of the fullness and swelling of the heart, which passions of all kinds do cause and induce" (Bacon, 2001: 181). To Bacon, man's life can be strengthened by the blessings of friendship and unity which encourages him to face any challenges just to win over it; not to be defeated.

\section{(ii.) Advocating the Importance of Knowledge}

Knowledge enables us to express ourselves confidently, help us to take decision rightly and gives us pleasure in leisure: "Studies serve for delight, for ornament, and for ability" (Bacon, 2001: 347). The more man will be engaged in gaining knowledge, the more he will be able to unveil the mysteries of creations and will know what the purpose of life should be. Knowledge is the one and only way to get human free from darkness and confusions of all sorts. In "Of Studies", Bacon tries his best to move mankind to books and to study. He suggests that we should not read to make us the so called learned but to make a practical use of knowledge in our life: "Read not to contradict or confute, not to believe or take for granted, nor to find talk and discourse, but to weigh and consider" (Bacon, 2001: 347). If we will be able to gain a good result by making a practical use of knowledge in life then we need to inspire others to follow the same path to attain success and happiness. "Of Studies" repeatedly emphasizes that knowledge is the strongest weapon to fight against ignorance. It is that force which cleanses minds from all evil forces, makes people to think clearly and helps them take the just decision. Knowledge is that solo thing which makes man's life dignified in his personal and public affairs. It is that magnificent force 
which impels mankind not only to do good to himself but for others. "Of Studies" makes the appeal to continue the practice of achieving knowledge since it possesses the power to make people wise who will never be satisfied until he moves others to follow the same path.

\section{(iii.) Emphasizing on Performing One's Responsibility towards Others}

The quality which makes human race different and extraordinary is the tendency to live for others. Men should never hesitate to dedicate themselves for the sake of the fellow beings; for the betterment of others. The chief concern of human society is to encourage man to treat others the way they want to be treated, and unite together upon common values. The demand of humanity is to inspire man to secure the heart from enmity against all in general, to intend good for them, to give them sincere counsel, and to love for them what he loves for himself. Very practically Bacon in "Of Great Place" asserts that man should use each minute of life to make him the ablest one to his life a better one which will definitely help him perform the responsibilities towards others. He also states that after attaining high position a man will be able to do both good and evil work whereas "the latter is a curse" (Bacon, 2001: 67). It would be better for a man not to have any power at all than to have power which permits him to do evil. The purpose of man's life should be to perform noble and meritorious tasks for others. Man always should try to relieve the sufferings of others by standing beside them in their wretched condition. After having performed such tasks, man is to enjoy rest just as God, according to Christianity, enjoyed rest after having created the universe: "For if a man can be a partaker of God's theatre, he shall like-wise be partaker of God's rest" (Bacon, 2001: 69).

\section{(iv.) Motivating People to be on the Track of Truth and Honesty}

Man should abandon the habit of telling lies and adopting dishonesty. False hope, false promise, false judgment, false opinion and deceit only make human life miserable. In the essay, "Of Truth", Bacon says, "Truth is the supreme good for human beings" (Bacon, 2001: 02). The inquiry of truth may be described as the wooing of it; the knowledge of truth may be described as the presence of it; and the belief of truth may be described as the enjoying of it. Bacon opines that the greatest pleasure for a man is the realization of truth. He believes that standing upon a vantage ground of truth, a man could survey the errors, falsehoods, and follies prevailing in the society. He feels that all the conducts of human beings should be based upon truth and honesty. An honest and straightforward dealing from a man show the dignity and 
honorable quality of that person. Falsehood brings nothing but disgrace. People should not be confused by thinking that when dishonesty makes success available and quick, it is to be accepted. Deceit can bring forth success shortly but soon disgrace and suffering meets the man which cannot be withdrawn even not after death. Ironically Bacon states that in telling a lie "a man is brave towards God but coward towards men" (Bacon, 2001: 07). He believes that falsehood is wicked, and such wickedness will duly receive its consequences in this earth and in the life here after. Only the spirits of truth can make one's life free of complexities and tensions and thus, instill the life with satisfaction and peace.

\section{(v.) Showing the Ways to Check Evil Temptation}

Jealousy, hypocrisy, deceit, greed and wrath are those aspects which can annihilate good qualities of human beings. They are the evil and poisonous spirits which, if left uncontrolled, can alter human beings into beasts and can lead them to commit any kind of barbarous crime giving birth to vicious anarchy in the society. Bacon in "Of Nature in Men" reveals that the temperament or evil force of a human being could be kept under controlled through teaching and preaching and most importantly, through a regular and sincere practice or a habitual endeavor: "Force maketh nature more violent in the return; doctrine and discourse maketh nature less importune, but custom only doth alter and subdue nature" (Bacon, 2001: 272). Bacon suggests that if a man wants to control his evil temptation, he should try to do so neither through excessive efforts nor through feeble attempts because in the former case he is likely to meet frequent failures and in the latter he will be able to achieve only small result. In the beginning, a man should practice self-control with certain external aids; but after some time he should practice it by putting hurdles in his own way. Bacon believes that a man's nature includes both fruitful tendencies and harmful ones. Let a man, therefore, nourish the former and crush the latter.

\section{(vi.) Providing Guideline to be Solvent and to Help Others}

In "Of Ambition" Bacon opines that an ambitious man who has the will to work hard and wants to do good to others is, of course, an honest man. Man's desire to get money makes man active and energetic and also prompts him to be dutiful towards his works. Through "Of Riches" Bacon suggests that though it will take a long time but it is better to follow the right method and work honestly to become rich. The most natural means to be rich is to improve the soil and cultivate it to grow crops. Besides, ordinary trades and professions are a source of honest money. Income from these 
sources can be increased by hard works and fair dealings. Again, if a man is lucky enough to try a new line of business, he will become wonderfully rich. If a man gets the exclusive right to trade in certain articles, he is sure to make money. If a man does not wish to take any risk in financial ventures, he cannot attain to great riches; and he, who risks everything in the hope of multiplying his wealth, may lose everything and become bankrupt. The best course, therefore, is partly to play safe and partly to take risk. He who makes haste to become rich will most probably employ unfair means. Money gained through flattery, exploitation and dishonesty is the worst way. In "Of Expense" Bacon says that the rich should not spend their money lavishly. They should engage themselves in dignified deeds while helping people earnestly: "Riches are for spending, and spending for honour and good actions" (Bacon, 2001: 199).

\section{(vii.) Inspiring Man to Face Adverse Situation and be Practical}

Adversity may befall upon life but that does not mean that we are to lose hope and surrender to the trap of frustration. Bacon in "Of Adversity" says that the blessings of prosperity are certainly desirable but that the blessings of adversity are admirable. He also comments that in prosperity the chief virtue of human being is moderation, while in adversity the chief virtue of human being is the courage to face hardships. A man is expected to face misfortunes and disappointments of life with a firm resolve being aided by a strong confidence upon him. A man must remember that in a state of prosperity, a man is not without fears and annoyances; and a man in adversity is not without consolations and hopes. He must believe that good days are waiting to come. However, adversity nourishes a man's moral and spiritual personality and strengthens his inner resources. Just as the scent of spices becomes stronger if we crush them, and the fragrance of incense becomes greater if we burn them, so the virtue or the inherent strength of a man reveals itself to a greater degree when a man is oppressed by adversity. In a state of prosperity it is the vices of a man which find a favorable climate to flourish; but in a state of adversity it is the virtue which find a favorable soil to grow and develop: "Certainly, virtue is like precious odours, most fragrant when they are increased or crushed: for Prosperity doth best discover vice, but Adversity doth best discover virtue" (Bacon, 2001: 31).

\section{(viii.) Highlighting the Bond of Family}

Life in seclusion can only make a man frustrated. It distracts a man from the pleasure of living. Family truly works to inspire people strive for making life better and worthy. To Bacon, family is a place where love, sacrifice and discipline are exercised. 
He believes that family is a place where a man will become more disciplined and responsible in his affairs: "Certainly, wife and children are a kind of discipline of humanity" (Bacon, 2001: 47). A man having a wife and children get much scope to exercise the softer feeling of heart which will make him affectionate and generous in temperament. An unmarried man gets no opportunities for the exercise of his feelings of tenderness and affection and as a result, he has become more cruel and hardhearted than a married man. Besides, a married man learns how to devote himself chiefly for the well fare of others. A man having a family can fight against any misfortune and even against the enemy of the country in order to provide security to the members of his family. On the other hand, unmarried men may be the best friends, employers and subordinates but they are not always the best citizens. Having no responsibility, unmarried men find it easy to flee from the country when the country demands them most. Family is a place of mutual understanding, love and respect having the power to cast away all the frustrations and disappointment by providing a civilizing effect on life.

\section{(ix.) Showing the Ways of Right Parenting}

We have an essay under the title "Parents and Children" where Bacon advices parents to follow some guidelines to make their kids' lives unspoiled and truly strong. Parents ought not to make discrimination between brothers and sisters because when the children will grow up this sense of discrimination will turn into rivalry and then into hatred which "many times sorteth to discord when they are men, and disturbeth families" (Bacon, 2001: 43). Secondly, parents should not be miser in giving pocket allowance to their children. If they do so, very soon the children will associate with mean companies and will learn all the tricks to get the money in a dishonest way. So what should parents do? The answer is parents should imbibe a sense of making differences between right and wrong into children's minds so that if they get a lot of money, they will know where to spend them rightly. Again, parents should themselves choose the professions which they want their children to enter. But if children themselves choose a profession, parents should offer them all the supports to make them successful. Parents should be very much careful in upbringing their children. They are inspired to think that "The perpetuity by generation is common to beast; but memory, merit and noble works are proper to men" (Bacon, 2001: 43). What if physically they are to bid good bye to the world but they are to live in their offspring; they are to live in their child's thought and action. 


\section{(x.) Urging to Maintain Unity in Religions}

In The Religious Foundation of Francis Bacon's Thought, Mr. Mcknight attempts "to correct the persistent misconception of Bacon as a secular modern" (Mcknight, 2006: 155). The author explores that Bacon did not dismiss religion to promote human advancement. Rather the essayist believed that the goal of science and human life is not separated from the relationship among God, humanity and nature. "Religion being the chief hand of human society, it is a happy thing when itself is well contained within the true band of unity" (Bacon, 2001: 14). This is a well reputed message from Bacon expressed in "Of Unity in Religion" which states that the united force of religions keep human beings united. There exists not a single religion which supports compulsion by the name of religion. It is ignorance which switches on the trigger of violence by the name of religious practice. If there remains conflict in different religions or people from the same religion it will throw away faith, charity and peace from society. Bacon suggests that it is necessary to determine the bounds within which religion must maintain its unity. Certain fanatics are little interested in peace; what matters for them is strife and partnership. Other people are so lukewarm in matters of faith that they are willing to accommodate all points of view in religion. Both this extremes should be avoided. Followers of any religion would do well if they maintain unity to deal with the differences over minor matters. Another important idea that Bacon gives us is that neither persecution nor rebellion is desirable in the name of religion or to promote a particular religion. Man's duty to God should not nullify man's duty towards man. Rightly Bacon says that we cannot please God by committing devilish deeds of cruelty and barbarism to His creations.

\section{(xi.) Encouraging Man to Forgive Others}

Very often a man does wrong in order to make a financial gain or for fulfilling some purpose in evil manner or to win a higher position or for some other similar reason. And if a man does a wrong merely because of his malicious nature, it is best to ignore him as he is like the thorn or briar which can only prick and scratch but serve no useful purpose. It is better to forgive the evil doers because by taking revenge a man can settle a score with his enemy but if he refrains from taking revenge, he shows a moral superiority over his enemy as Bacon states in "Of Revenge": "Certainly, in taking revenge, a man is but even with his enemy, but by passing it over, he is superior: for it is prince's part to pardon" (Bacon, 2001: 27). Moreover, if a man aims at never pardoning his enemy and taking revenge, he keeps himself in a state of torment because he is unable to forget the wrongs that he has suffered. Further, a man 
should remember that which belongs to the past is gone forever and is beyond recall. An injury that is done to him in the past should be forgotten because those, who concern themselves with affairs of the past, are unwise and merely waste their energy. Later, in a didactic mood, Bacon advises all to forget the past and forgive the evil doers and to take a step ahead to make a better future.

\section{(xii.) Marking the Standards of a Great Leader}

The essay "Of Empire" deals with the qualities of a leader of a nation who should be a man of intellect and of strong determination and power. He must combine harshness with mildness. He will do a lot of damage to the nation if there are abrupt changes in his mood from harshness to mildness and vice versa: "And certain it is, that nothing destroyeth authority so much as the unequal and untimely interchange of power pressed too far, and relaxed too much" (Bacon, 2001: 127). A leader should set before him the best examples of the past. Nor should he ignore the examples of those who did not, in the past, perform their duties well because, only keeping the mistakes of such persons in mind, he will be able to avoid such mistakes. He should also keep scrutinizing his own performance from time to time in order to ensure that his work is not deteriorating. Moreover, he should also take precautions to keep away danger. So far as neighboring countries are concerned, a leader should be alert and watchful. He should be a dynamic and energetic man who could only be compared with a planet which gets no rest but keeps moving all the time. A leader will not stray away from the path of virtue as long as he remembers the fact that he is undertaking the charge given to him by God.

\section{(xiii.) Asserting the True Spirits of a Country}

While describing the features of a leader, there are some essays which also inspire the readers to love the motherland to the highest extent. The greatness of a country does not depend either upon the vastness of its territory or upon the vastness of its population or upon its wealth. A country can attain greatness only if its people are stout and war-like. It is the spirit and courage of the people that matters. Bacon in "Of the True Greatness of Kingdoms and Estates" states that a state may be very wealthy but if its people do not possess a true spirit and feeling to sovereignty, it will be conquered by another country. Furthermore, a state must pay proper attention to its nobles and gentlemen, merchants and peasants that means, to all classes of people. A country should celebrate unity and should be a shepherd to nourish all sorts of goodness and be strong in case of demolishing evil. The essay strongly demonstrates 
that development of a country depends on its denizens' patriotism and it is the responsibility of a country to confirm the rights of its citizens which will let them sacrifice anything for the country. "Of Judicature" asserts that a country must practice proper rule of law which ensures the equity and balance among its citizens. The system of justice ought to keep free from any question and any corruption. A country must make a proper balance between the spirits of the youth and the experience of the aged ones. Moreover, mastery of the sea is essential for the greatness of a kingdom. A great state should never tolerate a threat to its borders, injury to its trade, or insult to its ambassadors from other nations. It should always be ready to offer any kind of aid even military aid to those countries with whom it has any kind of alliance. A great country must have a national spirit enjoying, at the same time, a good international relationship.

\section{Concluding Words}

The essays, shortly analyzed here, never deal with any metaphysical or abstruse ideas rather they speak about man's natural and normal life. The essays never allow a man to go to the wrong ways rather they push him to follow the right ones. The removal of superstitions, refinement of manners, and improvement of morals are all included in the essays. They speak about how to be a perfect man, how to deal with the challenges of the world, how to contribute greatly to the building of a family, society and thus, to the nation. His essays are an apt guideline to make a man perfect. The essays are a better prescription to all the wandering minds in search of the aim of life. Bacon firmly believes that a united effort of all the perfect human beings can build a perfect society; a society which will be free from poverty, which will be a safe and secure place for all, where a sense of equality will prevail and where people will be involved in the work of intelligence, benevolence, precision and dignity. He wants to have a land where the people and the leader will work together for the sake of a peaceful nation. His essays are much inspirational to cast away all which are vicious and to follow all which lead to amity and perfection. It is the demand of time to study his essays and talk about them so that their spirits could be imbibed into human hearts with a zeal to demolish violence and to attain excellence. This spirit will certainly confirm the rising of better human beings who will work together for the establishment of a peaceful land where people will feel secured with contented smile in their faces. 


\section{References}

Al Qur'an. (1996). Hyderbad-India: Eliassi Family Book Service.

Alam, M. U. (2014). Utilitarianism in Francis Bacon's Essay, Available at http://www.academia.edu/13729730/Francis_Bacon_Depicts_Utilitarianism_in_His_Es says, Accessed on August 2016.

Anderson, H. F. (1962). Francis Bacon: His Career and His Thought, Los Angeles: University of Southern California Press.

Bacon, F. (2001). Bacon's Essays: A Selection, Dhaka: Friends' Book Corner.

Bowen, C. D. (1993). Francis Bacon: The Temper of a Man, New York: Fordham University Press.

Islam, M. N. (2012). Social Planning and Policy, Dhaka: Tasmia Publications.

Islam, M. N. (2012). Social Problems and Analysis Technique, Dhaka: Tasmia Publications.

Islam, R. (Ed.). (2011). Political Sociology, Dhaka: The Social Science Publications.

Mcknight, A. S. (2006). The Religious Foundation of Francis Bacon's Thoughts, Columbia: University of Missouri Press.

Mujahid, A. M. (2011). Two Hundred Golden Hadiths, Riyadh: Darussalam Publication.

Peterson, J. T. and Til, J. (2004). Available at http://www.icnl.org/research/journal/vol61ss/art_5.htm.com, Accessed on August 10, 2016.

Sarah and Haris. (2014). Only 11 Countries Are Not Involved in Conflict, Available at http://www.express.co.uk/news/world/499884/Global-Peace-Index-reveals-only-11countries-are-not-involved-in-conflict. Accessed on July 2016.

Shakespeare, W. (2000). A Selection of Shakespeare' Sonnets, Dhaka: Friends' Book Corner. World Health Organization. (2002). World Report on Violence and Health, Available at http://www.who.int/violence_injury_prevention/violence/world_report/en/summary_en. pdf, Accessed in August 2016. 